\title{
DIAMETER INCREMENT DISTRIBUTION ALONG THE STEM OF NARROW-LEAVED ASH IN RESPONSE TO THINNING INTENSITY
}

\author{
PORAST PROMJERA UZDUŽ DEBLA POLJSKOG JASENA \\ KAO REAKCIJA NA INTENZITET PROREDA
}

\author{
Ali Kemal ÖZBAYRAM ${ }^{1}$
}

\begin{abstract}
SUMMARY
Narrow-leaved ash (NLA, Fraxinus angustifolia) is an important tree species due to its rapid development and valuable wood. In the pure NLA plantations in Turkey, little is known about the effects of thinning intensity on the diameter increment of different parts of the tree stem. In 2005, a thinning experiment with three thinning intensities (control: $0 \%$; moderate: 19\%; heavy: $28 \%$ of basal area removed) was established in an NLA plantation in Sakarya, Turkey. Seven years after thinning, a total of 25 sample trees representing dominant and co-dominant trees were felled, and cross-sectional stem samples were taken for analysis. The diameter at breast height $\left(\mathrm{d}_{1.30}\right)$ and $\mathrm{d}_{1.30}$ increments of the co-dominant trees with the moderate and heavy treatments were similar to each other and greater than in the controls. The seven-year $\mathrm{d}_{1.30}$ increments of the dominant trees in the heavy-treatment plot were approximately $20 \%$ greater than in the other treatments plots. The highest diameter increments in both dominant and co-dominant trees for all treatments were determined at the $0.30 \mathrm{~m}$ and $17.30 \mathrm{~m}$ section heights. The sample tree diameter increments of between $1.30 \mathrm{~m}$ and $13.30 \mathrm{~m}$ were similar within their classes. In conclusion, heavyintensity thinning of up to $28 \%$ did not cause tapering in the NLA plantation stems, and thus, heavy thinning can be recommended for NLA trees.
\end{abstract}

KEY WORDS: Narrow-leaved ash, Fraxinus angustifolia, thinning, stem form

\section{INTRODUCTION UVOD}

In general, in order to keep the large and heavy stem standing, the bottom portion of a tree is thicker and heavier and the upper portions are thinner and lighter. However, there are mechanical and physiological factors that change the general shape of the stem (Gürocak, 2011). Mechanical effects such as wind and snow can cause the stem to either bend or break. When silvicultural treatments are carried out regularly in established stands, the stem's resistance against mechanical effects is enhanced and a fuller stem shape is attained.

Thinning has been the most important silvicultural practice in broadleaved stands (Saatçioğlu, 1971) and can result in larger tree diameter, improved stem quality, increased merchantable volume and yield value and shortened rotation time (Hibbs et al., 1989; Mayor and Rodà, 1993; Cameron et al., 1995; Nowak, 1996; Oliver and Larson, 1996; Miller, 1997; Medhurst et al., 2001; Juodvalkis et al., 2005; Rytter and Werner, 2007). In broadleaved tree species the aim of 
thinning is usually to improve the quality of the final crop (Savill et al., 1997).

Dominant trees form a stronger and more conical stem, while suppressed trees form a cylindrical and weaker stem. In general, the effect of thinning is seen in the form of crown expansion, and as a result, the diameter growth can be further increased faster at the lower parts of the stem than at the upper part. Thus, the stem may become more conical in shape. For this reason, the increment at breast height provides ample information about the growth trend; however, it is not useful for quantitative estimation of stem taper and stem volume change (Smith et al., 1997).

Previous studies have shown that there is a rapid increment in diameter at the base of the stem after thinning (Pukkala et al., 1998; Tasissa and Burkhart, 1998). Subsequently, compared to a non-thinned stand, in a heavily thinned stand there may be substantial increments in the diameter of the upper parts of the remaining tree stem without a temporary standstill in the diameter increment at the base (Hilt and Dale, 1979; Mäkinen and Isomäki, 2004b; Pukkala et al., 1998; Tasissa and Burkhart, 1998). However, this growth response to thinning diminishes over time (Tasissa and Burkhart, 1998).

The response to thinning can be different along the stem. A more conical stem can be formed immediately after the thinning by freeing a tree of competition and by encouraging more xylem production at the base level than at higher levels. Thus, thinning can have a direct impact on the shape and build of the remaining trees (Arbaugh and Peterson, 1993; Larson, 1963; Tasissa and Burkhart, 1998). Kalıpsız (1998) stated that the tree-ring width along the stem depends on the relationship to neighboring trees and that an increment in diameter at the base of the stem would result in a greater diameter increase in the lower part of the stem which would lead to formation of a weak stem. There are different opinions about the effect of thinning on the diameter increments in different parts of the stem (Adegbeihn, 1982; Eler, 1988; Eler and Keskin, 1991; Mäkinen and Isomäki, 2004b; Morris et al., 1994; Weiskittel et al., 2009). As the effect of thinning on the diameter increment at different heights along the stem is not clear, more research is needed (Peltola et al., 2002).

Narrow-leaved ash (NLA, Fraxinus angustifolia) is a tree having great ecological and economic importance for lowland forests because of its valuable timber and its rapid development ability (Çiçek et al., 2013; Drvodelić et al., 2016; Kranjec et al., 2017). In Turkey it grows in riparian areas and is found as scattered trees or in small groups in mixed hardwood stands in mountainous areas (0-2000 m) (Boshier et al., 2005; Davis et al., 1988). Almost all of the NLAdominated lowland forests in Turkey have been converted to pure NLA plantations over the last 50 years. However, information on the silvicultural practices that should be applied in these plantations, especially on the growth effects of thinning intensity, is lacking. Although there have been numerous studies on the effect of thinning intensity on stem diameter growth in various tree species, there is limited information on the effect of thinning on the diameter increment distribution along the stem.

The purpose of this study, carried out on a 22-year-old NLA plantation, was to evaluate the seven-year results of the effects of different thinning intensities on the diameter and diameter increments at different heights along the stems of the dominant and co-dominant trees.

\section{MATERIAL AND METHODS MATERIJALI I METODE}

\section{Study site - Mjesto istraživanja}

The study site was established on a pure NLA plantation situated on bottomland in the Sakarya-Hendek region $\left(40^{\circ}\right.$

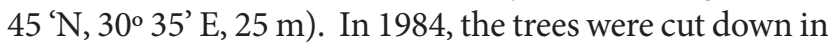
natural stands having NLA as the dominant species scattered among Ulmus laevis, U. minor, Quercus robur, Q. hartwissiana and Acer campestre. The General Directorate of Forestry then planted bare-root NLA seedlings (aged $0+1$ year) with $3.7 \times 3.7 \mathrm{~m}$ initial spacing $\left(730\right.$ tree ha $^{-1}$ ) (Çiçek et al., 2010). The pre-thinning age of the plantation was 22 years, and it contained 544 trees ha ${ }^{-1}$ having an average height of $24.0 \mathrm{~m}$, average crown base height of $15.0 \mathrm{~m}$ and basal area of $24,418 \mathrm{~m}^{2} \mathrm{ha}^{-1}$.

The deep alluvial soil at the site is poorly drained and heavy textured with a $\mathrm{pH}$ ranging from 7.0 to 7.8 . The ground water level may well reach up to the soil surface during the February-April period. According to data from the Adapazarı Meteorology Station ( $\left.40^{\circ} 46^{~} \mathrm{~N}, 30^{\circ} 23^{\prime} \mathrm{E}, 30 \mathrm{~m}\right)$, located about $15 \mathrm{~km}$ southwest of the site, the region receives an annual rainfall of $846 \mathrm{~mm}$. However, water deficiencies can occur in the site throughout the summer to the beginning of autumn. The average annual temperature is $14.3^{\circ} \mathrm{C}$, with the average temperature during the growth season (April - October) being $18.8^{\circ} \mathrm{C}$. The average relative humidity is around $72 \%$ (Çiçek et al., 2010).

\section{METHOD \\ METODA}

In autumn 2005, three-replicated thinning experiments were set up in the given plantation according to the randomized block design (Çiçek et al., 2010). For the experiment, the plot size was chosen as $63 \times 63 \mathrm{~m}(0.397 \mathrm{ha})$, and a $15-\mathrm{m}$ wide area on the sides of the plots was accepted as an isolation strip. Sampling quadrats of $33 \times 33 \mathrm{~m}(0.109$ ha) in the center of the nine plots were used for measurement and evaluation purposes. All the trees in the sampling quadrats were marked, and their diameter at breast height $\left(\mathrm{d}_{1,30)}\right.$ was measured using calipers with $\mathrm{mm}$ precision. The 
basal area was removed from the stand by applying three different selective thinning intensities of $0 \%$ (control), 18.9\% (moderate) and $28.2 \%$ (heavy). The trees selected for thinning in each plot were then marked, felled and removed from the stand (Çiçek et al., 2010).

In November 2012, the $d_{1.30}$ of each numbered standing tree in the experimental plots was re-measured with precision calipers. The seven-year diameter increments of the plot were determined by subtracting the 2005 plot diameter averages (of the remaining stands) from the 2012 diameter averages. Three sample trees were selected from each plot for a total of 27 trees. Of the three sample trees selected in each parcel, two represented the co-dominant trees and one represented the dominant tree. The selected sample trees, having normal stem and crown shapes, represented the seven-year diameter increase in their class for that plot.

After the northern sides of the selected sample trees were marked, they were felled and their height was measured. After the branches on the stem were removed, 4-5-cm thick disk samples were taken from different sectional heights $(0.30 \mathrm{~m}, 1.30 \mathrm{~m}, 3.30 \mathrm{~m}, 5.30 \mathrm{~m}, \ldots$, and 21.30$)$. The base diameters of the sample trees (soil level) and the number of annual rings in the bottom log were also recorded. Later, the cross-section disks representing the sample tree were placed separately in air-permeable sacks and transported to the laboratory. The sections were procured and measured for stem analysis according to the published works of Kalıpsız (1999) and Giray (1984).

In the laboratory, without allowing the sections to dry, a line was drawn across the diameter of the upper surface of each cross-section bisecting the core in the north-south direction. In addition, a diameter line was drawn in the east-west direction passing through the center perpendicular to the north-south diameter. All the rings of each section were counted and registered in the stem analysis form. Seven annual rings were then counted in each direction, from the outside to the inside, and the annual ring corresponding to this age was marked, indicating that the ring represented the radius of the tree without bark in 2005. The 2005 diameters without bark and the 2012 diameters with and without bark were measured on each section within an accuracy of $0.5 \mathrm{~mm}$. With the help of these measured diameters, the diameters without bark in 2005 and with and without bark in 2012 were calculated for each section. Thus, the relationship between the diameter without bark and the double-bark thickness was derived by using the values of the bark-free diameters of 2012 and the double-bark thickness values corresponding to these diameters $\left(\mathrm{R}^{2}=0.738\right)$, as in Equation (1).

$$
\mathrm{k}=0.0012 \mathrm{~d}^{2}+0.3456 \mathrm{~d}+1.2375
$$

where $\mathrm{k}$ is the thickness of the bark $(\mathrm{mm})$ and $\mathrm{d}$ is the sample diameter without bark $(\mathrm{cm})$.

In each sample tree, the diameter over bark of 2005 was subtracted from the diameter inside the bark of 2012, and the seven-year diameter increment of each section was calculated. In the sample trees, the arithmetic mean of the diameters of all sections was taken and the average stem diameters (2005 and 2012) and stem diameter increments for each sample tree were determined. In addition, the percentage of diameter increment was calculated as the ratio of the sevenyear diameter increment to the diameter of the year 2005.

\section{Statistical analyses - Statistička analiza}

First, the obtained data were subjected to variance analysis (ANOVA) to determine the effect of thinning intensity on the $d_{1,30}$ growth and increments of the sample trees. Variance analysis was then carried out to determine the effect of thinning intensity, cross-section height and thinning intensity $\times$ cross-section interaction on the diameters, diameter increments and percent of diameter increments of the sample trees (dominant and co-dominant) at different section heights. Analyses were performed separately for the dominant and the co-dominant trees. When the ANOVA results were found to be significant, the Duncan test was used to compare the averages. In evaluating the data, the SPSS (version 21) package statistical software was used and the results were regarded as statistically different at a level of $p<0.05$. Before the analyses, it was confirmed that the data of all variables exhibited a normal distribution and the variances were homogeneous.

\section{RESULTS}

REZULTATI

After the thinning, the mean $\mathrm{d}_{1.30}$ was similar in terms of treatments ( $p>0.05$; Table 1$)$ for the co-dominant and dominant trees in the remaining stand $(23.6$ and $27.8 \mathrm{~cm}$, respectively). Seven years later, the $\mathrm{d}_{1.30}$ of the dominant trees in all plots showed a similarity and the $\mathrm{d}_{1.30}$ of the co-dominant trees for the moderate and heavy treatments were similar, while being $12 \%$ greater than the control (Table 1 ).

The $\mathrm{d}_{1.30}$ increments of the co-dominant trees were similar in the thinned plots and greater than the control $(p<0.05)$. When each treatment plot was evaluated within itself and compared to the remaining plots after the thinning, the $d_{1.30}$ increment of the co-dominant trees had increased by $16 \%$ in the control plots and $22 \%$ in the thinned plots. Compared to the control treatments, the $\mathrm{d}_{1.30}$ of the co-dominant trees in the thinned plots had increased their diameter by $43 \%$ (Table 1). The $\mathrm{d}_{1.30}$ increments for the control and moderate treatments of the dominant trees were similar to each other and were lower than for the heavy treatment $(p<0.05)$. The $\mathrm{d}_{1.30}$ diameter increment in the heavy treatment plot was approximately $20 \%$ higher than in the other treatments plots. Moreover, when each treatment was compared within itself, the $d_{1.30}$ diameter increments were greater in the dominant trees than in the co-dominant trees (Table 1). 
Table 1. Influence of thinning intensity on the $d_{1.30}$ and seven-year diameter increment of $d_{1.30}$

Tablica 1. Utjecaj intenziteta proreda na $d_{1.30}$ te sedmogodišnji debljinski prirast $\mathrm{d}_{1.30}$

\begin{tabular}{|c|c|c|c|c|}
\hline $\begin{array}{l}\text { Class } \\
\text { Klasa }\end{array}$ & $\begin{array}{l}\text { Thinning } \\
\text { intensity } \\
\text { Intenzitet } \\
\text { proreda }\end{array}$ & $\begin{array}{l}\mathrm{d}_{1.30} \text { in } 2005 \\
\mathrm{~cm}\end{array}$ & $\begin{array}{c}\mathrm{d}_{1.30} \text { in } 2012 \\
\mathrm{~cm}\end{array}$ & $\begin{array}{c}\mathbf{d}_{1.30} \text { diameter } \\
\text { increment } \\
\text { debljinski prirast } \\
\mathrm{cm}\end{array}$ \\
\hline \multirow{4}{*}{$\begin{array}{l}\text { Co-dominant } \\
\text { trees } \\
\text { Suvladajuća } \\
\text { stabla }\end{array}$} & $\begin{array}{l}\text { Control } \\
\text { Kontrolni }\end{array}$ & 22.8 a (1.2) & 26.4 a (1.0) & 3.6 a $(0.4)$ \\
\hline & $\begin{array}{l}\text { Moderate } \\
\text { Umjereni }\end{array}$ & 24.2 a (0.5) & 29.4 a (0.7) & $5.2 \mathrm{~b}(0.5)$ \\
\hline & $\begin{array}{l}\text { Heavy } \\
\text { Jači }\end{array}$ & $24.2 \mathrm{a}(1.4)$ & 29.8 a (1.6) & $5.6 \mathrm{~b}(0.5)$ \\
\hline & $\begin{array}{l}p \text {-value } \\
P \text {-vrijednost }\end{array}$ & 0.114 & 0.001 & $<0.001$ \\
\hline \multirow{4}{*}{$\begin{array}{l}\text { Dominant } \\
\text { trees } \\
\text { Vladajuća } \\
\text { stabla }\end{array}$} & $\begin{array}{l}\text { Control } \\
\text { Kontrolni }\end{array}$ & $28.2 \mathrm{a}(2.1)$ & $34.1 \mathrm{a}(2.5)$ & 5.9 a $(0.6)$ \\
\hline & $\begin{array}{l}\text { Moderate } \\
\text { Umjereni }\end{array}$ & 26.7 a (1.6) & 32.4 a (1.6) & 5.7 a $(0.1)$ \\
\hline & $\begin{array}{l}\text { Heavy } \\
\text { Jači }\end{array}$ & 28.6 a (1.0) & 35.5 a (1.6) & $6.9 \mathrm{~b}(1.0)$ \\
\hline & $\begin{array}{l}p \text {-value } \\
P \text {-vrijednost }\end{array}$ & 0.350 & 0.192 & 0.048 \\
\hline
\end{tabular}

The parentheses indicate the standard deviation, the averages indicated by the same letter in the column are statistically insignificant $(p<0.05)$,

Vrijednosti u zagradama pokazuju standardnu devijaciju, Prosječne vrijednosti označene istim slovom u stupcu nisu statistički značajne $(P<0,05)$,

The effects of thinning intensity and cross-section height on the mean stem diameter increment of the co-dominant and dominant trees were significant $(p<0.05)$. However, the ef-

Table 2, Influence of thinning intensity on the mean stem diameter increment of co-dominant and dominant trees

Tablica 2, Utjecaj intenziteta proreda na prosječni debljinski prirast suvladajućih i vladajućih stabala

\begin{tabular}{|c|c|c|}
\hline $\begin{array}{l}\text { Treatments } \\
\text { Tretiranje }\end{array}$ & $\begin{array}{l}\text { Diameter increment } \\
\text { Debljinski prirast } \\
\text { (cm) }\end{array}$ & $\begin{array}{c}\text { Percentage of diameter } \\
\text { increment } \\
\text { Relativni debljinski prirast } \\
(\%)\end{array}$ \\
\hline \multicolumn{3}{|c|}{$\begin{array}{l}\text { Co-dominant trees } \\
\text { Suvladajuća stabla }\end{array}$} \\
\hline $\begin{array}{l}\text { Control } \\
\text { Kontrolni }\end{array}$ & 4.42 a $(0.17)$ & $80.54 \mathrm{ab}(17.44)$ \\
\hline $\begin{array}{l}\text { Moderate } \\
\text { Umjereni }\end{array}$ & 5.24 b (0.19) & 64.25 a (10.51) \\
\hline $\begin{array}{l}\text { Heavy } \\
\text { Jači }\end{array}$ & 5.87 c (0.17) & 88.95 b (16.67) \\
\hline \multicolumn{3}{|c|}{$\begin{array}{l}\text { Dominant trees } \\
\text { Vladajuća stabla }\end{array}$} \\
\hline $\begin{array}{l}\text { Control } \\
\text { Kontrolni }\end{array}$ & 5.80 a $(0.21)$ & 87.34 a (23.04) \\
\hline $\begin{array}{l}\text { Moderate } \\
\text { Umjereni }\end{array}$ & 5.84 a $(0.21)$ & 90.33 a (21.68) \\
\hline $\begin{array}{l}\text { Heavy } \\
\text { Jači }\end{array}$ & $6.52 \mathrm{~b}(0.29)$ & 94.57 a (23.72) \\
\hline
\end{tabular}

The parentheses indicate the standard deviation, The averages indicated by the same letter in the column are statistically insignificant $(p<0.05)$,

Vrijednosti u zagradama pokazuju standardnu devijaciju, Prosječne vrijednosti označene istim slovom u stupcu nisu statistički značajne $(P<0,05)$, fect of the interaction of thinning intensity $\times$ cross-section height on the mean stem diameter increment was not significant $(p>0.05)$. The mean stem diameter increment of the co-dominant trees with heavy treatments $(5.8 \mathrm{~cm})$ was greater than that of the control plots $(4.4 \mathrm{~cm})$. The mean stem diameter increment of the dominant trees was similar in the control and moderate treatment plots $(5.8 \mathrm{~cm})$, whereas it was highest in the heavy treatment plots $(6.5 \mathrm{~cm})$ (Table 2).

The highest diameter increments in both stem classes were determined for the cross-section at heights of $0.30 \mathrm{~m}$ and $17.30 \mathrm{~m}$ without distinction of thinning intensity. The diameter increments and diameter increment percentages between stem heights of 1.30-13.30 m were very close. However, the diameter increment percentages in the sections at $15.30 \mathrm{~m}$ and higher had increased $(p<0.05)$ (Table 3).

\section{DISCUSSION RASPRAVA}

In the NLA plantation, the greater increments for $\mathrm{d}_{1,30}$ and mean stem diameter were in the heavily thinned plots. There have been a number of studies showing that the intensity of thinning increases the breast height diameter in NLA (Çiçek et al., 2013) and other broadleaved species (Andrašev et al., 2012; Bobinac and Andrašev, 2006; Bréda et al., 1995; Clatterbuck, 2002; Hibbs et al., 1995; Juodvalkis et al., 2005; Kerr, 1996; Makineci, 2005; Mayor and Rodà, 1993; Meadows and Goelz, 2002; Medhurst et al., 2001; Özbayram, 2015; Tüfekçioğlu et al., 2005). On the other hand, Eler (1988) reported that the diameter increments at $0.30 \mathrm{~m}$ and $\mathrm{d}_{1.30}$ and in the middle part of the stem were greater for the heavy thinning than in the control plot. This positive effect of thinning intensity on the diameter increment can be explained by the fact that that the remaining trees in the stand benefited from the increase in light, water and nutrients.

For all classes and treatments, the highest diameter increments were observed in the sections at heights of 0.30 and $17.30 \mathrm{~m}$ (Table 3). Trees give priority to thickening at the bottom of the stem in order to survive (Smith et al., 1997). Therefore, it is believed that the diameter increment will be greater at the $0.30 \mathrm{~m}$ section than at other section heights. In some studies, it has been noted that the diameter of the stem increased rapidly at the bottom (Pukkala et al., 1998; Tasissa and Burkhart, 1998), followed by an increase in the upper parts of the stem (Hilt and Dale, 1979; Mäkinen and Isomäki, 2004a; Mäkinen and Isomäki, 2004b; Pukkala et al., 1998; Tasissa and Burkhart, 1998). On the other hand, the increase in diameter at $17.30 \mathrm{~m}$ could have been caused at this height because it represents the area where the branches are most concentrated. It is necessary for the crown to thicken and grow to form a solid connection with the tree structure in order to shield it against mechanical effects. Kalpsiz (1998) 
Table 3. Diameter increment and relative diameter increment at different section heights of sample trees Tablica 3. Debljinski prirast i postotci debljinskog prirasta na različitim visinama uzorkovanih stabala

\begin{tabular}{|c|c|c|c|c|}
\hline \multirow[t]{3}{*}{$\begin{array}{l}\text { Stem cross-section } \\
\text { height } \\
\text { Visina presjeka debla } \\
(\mathrm{m})\end{array}$} & $\begin{array}{l}\text { Diameter increment } \\
\text { Debljinski prirast } \\
\text { (cm) }\end{array}$ & $\begin{array}{c}\text { Percentage of diameter } \\
\text { increment } \\
\text { Relativni debljinski prirast } \\
(\%) \\
\end{array}$ & $\begin{array}{l}\text { Diameter increment } \\
\text { Debljinski prirast (cm) }\end{array}$ & $\begin{array}{c}\text { Percentage of diameter } \\
\text { increment } \\
\text { Relativni debljinski prirast } \\
(\%)\end{array}$ \\
\hline & \multicolumn{2}{|c|}{ Co-dominant trees } & \multicolumn{2}{|c|}{ Dominant trees } \\
\hline & \multicolumn{2}{|c|}{ Suvladajuća stabla } & \multicolumn{2}{|c|}{ Vladajuća stabla } \\
\hline 0.30 & $6.41 \mathrm{~d}(0.50)$ & 17.46 a (1.28) & $7.82 f(0.73)$ & 20.18 a (1.96) \\
\hline 1.30 & $4.90 \mathrm{ab}(0.24)$ & 20.52 a $(0.88)$ & $5.83 \mathrm{abcd}(0.41)$ & 21.32 a (1.20) \\
\hline 3.30 & 4.23 a $(0.45)$ & 20.77 a (2.37) & $5.35 \mathrm{abc}(0.29)$ & 23.58 a (1.25) \\
\hline 5.30 & $4.58 \mathrm{ab}(0.22)$ & 24.80 a (1.17) & $5.16 \mathrm{ab}(0.33)$ & 24.71 a (1.45) \\
\hline 7.30 & 4.24 a $(0.34)$ & 24.72 a (1.77) & $5.07 \mathrm{ab}(0.39)$ & 26.85 a (2.29) \\
\hline 9.30 & $4.57 \mathrm{ab}(0.35)$ & 29.53 a (2.44) & 5.74 abcd (0.37) & 35.07 a (2.77) \\
\hline 11.30 & $4.78 \mathrm{ab}(0.26)$ & 35.32 a (2.74) & $5.69 \mathrm{abcd}(0.23)$ & 37.29 a (1.87) \\
\hline 13.30 & $5.18 \mathrm{~b}(0.39)$ & 46.78 a $(5.11)$ & $5.85 \mathrm{abcd}(0.22)$ & 42.90 a (2.95) \\
\hline 15.30 & $5.37 \mathrm{bc}(0.27)$ & $57.58 \mathrm{ab}(5.15)$ & 6.57 cde $(0.50)$ & $62.18 \mathrm{ab}(6.16)$ \\
\hline 17.30 & $6.36 \mathrm{~d}(0.36)$ & 97.16 b (10.89) & $7.17 f(0.36)$ & $103.80 \mathrm{ab}(20.97)$ \\
\hline 19.30 & $6.08 \mathrm{~cd}(0.29)$ & 193.54 c (36.85) & $6.70 \operatorname{def}(0.47)$ & 145.99 b (29.35) \\
\hline 21.30 & 5.46 bc $(0.32)$ & $277.37 \mathrm{~d}(48.02)$ & 6.27 bcde $(0.67)$ & 257.45 c (50.35) \\
\hline
\end{tabular}

The parentheses indicate the standard deviation, The averages indicated by the same letter in the column are statistically insignificant $(p<0.05)$ Vrijednosti u zagradama pokazuju standardnu devijaciju, Prosječne vrijednosti označene istim slovom u stupcu nisu statistički značajne $(P<0,05)$

stated that the highest peak development on the tree stem was found at the middle part of the crown.

Diameter increments at all sections of the dominant trees were greater than those of the co-dominant trees (Table 2). In similar studies, it was determined that dominant trees displayed more diameter increase than co-dominant trees (Boncina et al., 2007; Medhurst et al., 2001; Smith et al., 1997). This can be explained by the fact that the dominant trees had developed better crowns and therefore, had received more benefit from light and also because they had developed a better root system to reach more water and nutrients. Assmann (1970) indicated that the dominant trees in a plot secured more solar energy and had higher levels of photosynthesis and growth (Nyland, 1996).

According to this study, when each stem class was compared to its own control treatments, the relative response of the co-dominant trees to heavy thinning was higher than that of the dominant trees (Table 3). Since the co-dominant trees exhibited smaller diameter increments in the control plots than did the dominant trees, the increments of the co-dominant trees in the heavily thinned plots appeared to be relatively higher. In the control treatment, the diameter increments in the dominant trees were greater than those of the co-dominant trees because the dominant trees were less affected by light competition. It can be said that in dominant trees, the diameter increments are more prominent due to the competition for water and plant nutrients rather than for light. In the soil moisture measurements made at this site it was determined that in the summer, the amount of water in the soil was higher in the thinned plots than in the control plots (Çiçek et al. 2010).

\section{CONCLUSION} ZAKLJUČAK

The fact that the thinning intensity $\times$ cross-section height interaction did not significantly affect the diameter increment demonstrated that the diameter increments at different cross-sectional heights were parallel in all treatments. Therefore, the influence of thinning on the diameter increment at each section height was similar to the effect on the $\mathrm{d}_{1.30}$ increment. The fact that the stem diameter increments at $1.30-11.30 \mathrm{~m}$, which are more important in commercial terms, were similar suggests that, according to the sevenyear results, heavy thinning did not cause tapering in the stem. Consequently, subject to further research, heavy thinning can be recommended in NLA plantations.

The seven-year results achieved with this study may not provide sufficient information on how thinning in the NLA plantations affects the diameter increments along the stem. The results of thinning may vary from species to species and depending on growth environment and stand characteristics. The results obtained in this study can be assessed by comparison with longer duration thinning treatments performed in NLA plantations having different ages and characteristics.

\section{REFERENCES}

REFERENCE

- Adegbeihn, J., 1982: Preliminary results of the effects of spacings on the growth and yield of Tectona grandis Linn. F., Ind For, 108(6): 423-430. 
- Andrašev, S., M. Bobinac, S. Rončević, M. Vučković, B. Stajić, G. Janjatović, Z. Obućina, 2012: Učinci prorjede u nasadu topole klona I-214 rijetke sadnje. Šumarski list, 136(1-2), 37-54.

- Arbaugh, M.J., D.L. Peterson, 1993: Stemwood production patterns in ponderosa pine: effects of stand dynamics and other factors, Res. Paper PSW-RP-217, Pacific Southwest Research Station, Forest Service, U.S. Department of Agriculture: 11 p., Albany, CA.

- Assmann, E., 1970: Principles of forest yield study, Pergamon Press, Oxford.

- Bobinac M., S. Andrašev, 2006: Effects of heavy thinning on Turkey oak (Quercus cerris L.) tree and stand increment, Šumar. inst. Jastrebar. 41 (1-2): 31-38.

- Boncina, A., A. Kadunc, D. Robic, 2007: Effects of selective thinning on growth and development of beech (Fagus sylvatica L.) forest stands in south-eastern Slovenia, Ann Forest Sci, 64(1): 47-57.

- Boshier, D., J. Cordero, S. Harris, J. Pannell, S. Rendell, P. Savill,... \& B. Eriksen, 2005: Ash species in Europe: Biological characteristics and practical guidelines for sustainable use, Oxford Forestry Institute, University of Oxford, United Kingdom.

- Bréda, N., A. Granier, G. Aussenac, 1995: Effects of thinning on soil and tree water relations, transpiration and growth in an oak forest (Quercus petraea (Matt.) Liebl.), Tree Physiol, 15(5): 295306.

- Cameron AD, R.A. Dunham, J.A. Petty, 1995: The effects of heavy thinning on stem quality and timber properties of silver birch (Betula pendula Roth). Forestry 68:275-286. doi:10.1093/ forestry/68.3.275

- Clatterbuck, W.K., 2002: Growth of a 30-year cherrybark oak plantation 6 years after thinning, In: K.W. Outcalt (ed), Proceedings of the Eleventh Biennial Southern Silvicultural Research Conference, Gen. Tech. Rep. SRS-48, USDA Forest Service, 189192, Asheville, NC, USA.

- Cicek, E., F. Yilmaz, A.K. Özbayram, M., Efe, M. Yilmaz and A. Usta, 2013: Effects of thinning intensity on the growth of narrow-leaved ash (Fraxinus angustifolia subsp. oxycarpa) plantations, Turk J Agric For, 37 (1): 97-104.

- Çiçek, E., M. Yılmaz, F. Yılmaz, A. Usta, 2010: Effects of thinning on growth and some soil properties in narrow-leaved ash (Fraxinus angustifolia) plantations, Project Report. TÜBİTAK TOVAG 105O519, Düzce, Turkey.

- Davis, P.H., J. Cullen, M.J.E. Coode, 1988: Flora of Turkey and the East Aegean Islands, 10 vol., Edinburgh University Press, Edinburgh.

- Drvodelić, D., D. Ugarković, M. Oršanić, V. Paulić, 2016: The Impact of Drought, Normal Watering and Substrate Saturation on the Morphological and Physiological Condition of Container Seedlings of Narrow-Leaved Ash (Fraxinus angustifolia Vahl). South-east European forestry, 7(2). doi:10.15177/seefor.16-11.

- Eler. Ü., 1988: Antalya bölgesi doğal kızılçam (Pinus brutia Ten.) meşcerelerinde aralama ve hazırlama kesimlerinin artım ve büyüme yönünden etkileri, Ormancılık Araştırma Enstitüsü Yayınları, 203 p., Ankara.

- Eler, Ü., S. Keskin, 1991: Antalya yöresi kızılçam (Pinus brutia Ten.) ağaçlandırma alanlarında geçikmiş ilk aralamalarda uygulanacak silvikültürel işlemlerin gelişme durumu üzerine etkileri, Ormancılık Araştırma Enstitüsü Yayınları, 229: 1-124, Ankara.

- Giray, N., 1984: Gövde Analizi, Ormancılık Araştırma Enstitüsü Dergi Serisi, 49: 9-44.
- Gürocak, H., 2011: Doğu kayını (Fagus orientalis lipsky)'nda bazı ağaç şekil katsayılarının gögüs çapı ve boya göre gelişimleri ve karşılaştırılmaları, SDÜ Fen Bilimleri Enstitüsü, Isparta.

- Hibbs DE, W.H. Emmingham, M.C. Bondi, 1989: Thinning Red Alder: Effects of Method and Spacing. Forest Science 35:16-29

- Hibbs, D.E., W.H. Emmingham, M.C. Bondi, 1995: Responses of red alder to thinning, West J Appl For, 10(1): 17-23.

- Hilt, D.E., M.E. Dale, 1979: Stem form changes in upland oaks after thinning, Forest Service Research Paper Ne-433: 1-7.

- Juodvalkis, A., L. Kairiukstis, R. Vasiliauskas, 2005: Effects of thinning on growth of six tree species in north-temperate forests of Lithuania, Eur J For Res, 124(3): 187-192.

- Kalıpsı, A., 1998: Orman Hasılat Bilgisi, İstanbul Üniversitesi Yayın No. 3052/328, İstanbul.

- Kalıpsiz, A., 1999: Dendrometri, İstanbul Üniversitesi Orman Fakültesi Yayın No: 3194-354, İstanbul.

- Kerr, G., 1996: The effect of heavy or 'free growth' thinning on oak (Quercus petraea and Q. robur), Forestry, 69(4): 303-317.

- Kranjec, J., M. Milotić, M. Hegol, D. Diminić, 2017: Fungus-like organisms in the soil of declining Narrow-leaved ash (Fraxinus angustifolia Vahl). Šumarski list, 141(3-4), 115-122.

- Larson, P.R., 1963: Stem form development of forest trees, Forest Science, Supplement 5: 9.

- Makineci, E., 2005: Thinning effects on diameter increment and some soil properties in sessile oak (Quercus petrea (Matlusch) Lieb.) coppice forest, SDÜ Journal of Forest Faculty, 2: 1-10.

- Mäkinen, H, A. Isomäki, 2004a: Thinning intensity and longterm changes in increment and stem form of Norway spruce trees, Forest Ecol Manag, 201(2-3): 295-309.

- Mäkinen, H., A Isomäki, 2004b: Thinning intensity and longterm changes in increment and stem form of Scots pine trees, Forest Ecol Manag, 203(1): 21-34.

- Mayor, X., F. Rodà, 1993: Growth response of holm oak (Quercus ilex $\mathrm{L}$ ) to commercial thinning in the Montseny mountains (NE Spain), Ann Sci Forest, EDP Sciences: 247-256.

- Meadows, J.S., J. Goelz, 2002: Fourth year effects of thinning on growth and epicormic branching in a red oak-sweetgum stand on a minor stream bottom site in west-central Alabama, In: Proceedings of the Eleventh Biennial Southern Silvicultural Research Conference, Southern Research Station, Department of Agriculture Forest Service, 201-208, Asheville, NC, USA.

- Medhurst, J., C. Beadle, W. Neilsen, 2001: Early-age and laterage thinning affects growth, dominance, and intraspecific competition in Eucalyptus nitens plantations, Can J Forest Res, 31(2): 187-197.

- Miller GW 1997: Stand dynamics in 60-year-old Allegheny hardwoods after thinning. Canadian Journal of Forest Research 27:1645-1657. doi:10.1139/x97-134

- Morris, D.M., S. Hills, C. Bowling, 1994: Growth and form responses to pre-commercial thinning regimes in aerially seeded jack pine stands: 5th year results, Forest Chron, 70(6): 780-787.

- Nyland R. D., 1996: Silviculture: concepts and applications, The McGraw-Hill Companies, USA.

- Nowak CA 1996: Wood volume increment in thinned, 50- to 55-year-old, mixed-species Allegheny hardwoods. Canadian Journal of Forest Research 26:819-835. doi:10.1139/x26-091.

- Oliver CD, Larson BC (1996) Forest stand dynamics, Update edn. John Wiley \& Sons, Inc., New York. 
- Özbayram, A.K., 2015: Effect of different thinning intensity in beech forests in Düzce (Abstract), The 10th International Beech Symposium, Kastamonu, Turkey, 16 p.

- Peltola, H., J. Miina, I. Rouvinen, S. Kellomaki, 2002: Effect of early thinning on the diameter growth distribution along the stem of Scots pine, Silva Fenn, 36(4): 813-825.

- Pukkala, T., J. Miina, S. Kellomäki, 1998: Response to different thinning intensities in young Pinus sylvestris, Scand J Forest Res, 13(1-4): 141-150.

- Rytter, L., 1995: Effects of thinning on the obtainable biomass, stand density, and tree diameters of intensively grown grey alder plantations, Forest Ecol Manag, 73(1): 135-143.

- Rytter L, Werner M 2007: Influence of early thinning in broadleaved stands on development of remaining stems. Scandinavian Journal of Forest Research 22:198-210. doi:10.1080/ 02827580701233494

- Rytter, L., L.-G Stener, 2014: Growth and thinning effects during a rotation period of hybrid aspen in southern Sweden, Scand J Forest Res, 29(8): 747-756.
- Savill P, Evans J, Auclair D, Falck J (1997) Plantation silviculture in Europe. Oxford University Press, UK.

- Saatçioğlu, F., 1971: Orman Bakımı: Meşcere yetiştirmesine ait tedbirler, İÜ. Orman Fakültesi, İstanbul.

- Smith, D.M., B.C. Larson, M.J. Kelty, P.M.S. Ashton, 1997: The practice of silviculture: Applied Forest Ecology, Wiley, New York.

- Tasissa, G., H.E. Burkhart, 1998: An application of mixed effects analysis to modeling thinning effects on stem profile of loblolly pine, Forest Ecol Manag, 103(1): 87-101.

- Tüfekçioğlu, A., S. Güner, F. Tilki, 2005: Thinning effects on production, root biomass and some soil properties in a young oriental beech stand in Artvin, Turkey, J Environ Biol, 26(1): 91-95.

- Weiskittel, A., L.S. Kenefic, R.S. Seymour, L.M. Phillips, 2009: Long-term effects of precommercial thinning on stem form, volume, and branch characteristics of red spruce and balsam fir crop trees, Silva Fenn, 43(3): 397-409.

\section{SAŽETAK}

Poljski jasen (PJ, Fraxinus angustifolia) važna je vrsta stabla zbog svojeg brzog rasta i vrijednog drva, U posljednjih pedeset godina u Turskoj nizinska prirodna sastojina PJ pretvorena je u čiste plantaže PJ, Međutim, malo se zna o utjecaju intenziteta proreda na debljinski prirast različitih dijelova debla u čistim plantažama PJ u Turskoj. Prorjeđivanje je najvažnija praksa u uzgoju sastojina listača te može rezultirati većom debljinom stabla, povećanim tehničkim obujmom, vrijednosti međuprihoda, skraćenim vremenom ophodnje i poboljšanom kvalitetom debla, Reakcija na prored može se razlikovati uzduž debla. Prored može imati izravan utjecaj na oblik i građu preostalih stabala. Budući da utjecaj proreda na debljinski prirast na različitim visinama uz deblo nije razjašnjen, potrebna su daljnja istraživanja. Cilj ovoga rada je istražiti utjecaje različitog intenziteta proreda na promjer i debljinski prirast na različitim visinama uzduž debla vladajućih i suvladajućih stabala jasena. Godine 2005., proveden je eksperiment prorjeđivanja s tri intenziteta proreda (kontrolni: $0 \%$, umjereni: $19 \%$, jači: $28 \%$ temeljnice uklonjeno) na plantažama PJ s gustoćom nasada 3,7x3,7 i 22 godine starosti u Adapazar1, Turska, Sedam godina nakon proreda, posječeno je ukupno 25 stabala koja predstavljaju vladajuća i suvladajuća stabla, te nakon uklanjanja grana s debla, uzeti su uzorci od oko $4-5 \mathrm{~cm}$ debljine s različitih

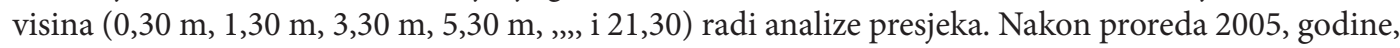
prsni promjer $\left(\mathrm{d}_{1,30}\right)$ bio je sličan u smislu tretiranja za suvladajuća $(23,6 \mathrm{~cm})$ i vladajuća stabla $(27,8$ $\mathrm{cm}$ ) u preostaloj sastojini, Vrijednost $\mathrm{d}_{1,30}$ iz 2012, godine i prirast $\mathrm{d}_{1,30}$ suvladajućih stabala u umjerenom $i$ jačem tretiranju bili su slični i veći od kontrolnih vrijednosti. Sedmogodišnji prirast $d_{1,30}$ dominantnih stabala bio je sličan kontrolnom i umjerenom tretiranju te je bio $16 \%$ manji od jačeg tretiranja $(6,9 \mathrm{~cm})$. Najveći debljinski prirast u svim tretiranjima kod vladajućih i suvladajućih stabala pronađen je na visini od 0,30 m i 17,30 m (7,50 cm kod vladajućih i 5,63 cm kod suvladajućihs tabala). Debljinski prirast uzorkovanih stabala između 1,30 m i 13,30 m bio je sličan unutar klase. Zaključno, jači prored do $28 \%$ nije uzrokovao promjenu oblika plantažnih debla PJ, te se stoga jači prored može preporučiti za stabla PJ,

KLJUČNE RIJEČI: poljski jasen, Fraxinus angustifolia, prorjeđivanje, oblik debla 